\title{
DEAR (DIGITAL EXPLORATION CAREER): HYPERMEDIA-BASED INNOVATION MEDIA FOR GUIDANCE AND COUNSELING TO EXPLORE STUDENT CAREER IN THE INDUSTRIAL REVOLUTION 4.0
}

\author{
Bayu Selo Aji', Cucu Kurniasih2, Berlin Fanta Rosiani3 ${ }^{3}$, and Caraka Putra Bhakti4 \\ 1,2,3,4Guidance and Counseling, Ahmad Dahlan University, Yogyakarta, Indonesia \\ e-mail: 1 bayu1715001165@webmail.vad.ac.id
}

\begin{abstract}
This scientific work aims to provide creative innovations in guidance and counseling services using the BK media to explore student careers. Entering the era of the Industrial Revolution 4.0, students today must have the ability and skills to predict a rapidly changing future, especially concerning career problems. Guidance and Counseling Teachers here play an essential role in developing students' potential, and one way is to optimize the role of Guidance and Counseling in schools by optimizing services about career exploration. For support services on career exploration, BK (Guidance and Counseling) media needed to improve students' understanding of the services provided. One of them uses DEAR (Digital Exploration Career) based media as an alternative and innovation that can use to explore students' careers. DEAR (Digital Exploration Career) is a hypermedia-based BK media. Each use of this media in service delivery also pays attention to students' needs, materials, entertainment, and evaluations so that the media is effective in service delivery even though sometimes without face to face. So that this media provides a new atmosphere and innovation in the provision of BK services so that they can run dynamically by the times. Then DEAR (Digital Exploration Career) Hypermedia-Based Bk Media Innovation is one solution that can use to explore students' careers in the industrial revolution era 4.0.
\end{abstract}

Keywords:4.0 Industrial Revolution, Guidance and Counseling, Innovation Media, Hypermedia, Career Exploration. 
Introduction "Surely Allah will not change people's condition before they change their conditions" (Surah Ar-Ra'd: 11). The translation of the Qur'anic verse implies the need for humans to change. Anyone who rejects change will be left behind because change is a necessity. One of the changes that we can feel and witness for ourselves is the change of era. Where era change fundamentally makes the interaction between individuals, between organizations, even between countries can be done very quickly because it only insulated by cyberspace. Changes always give real signs and leave traces in human life marked by many things, one of which is a change in the industrial era. The history of the industrial revolution began in stages, from industry 1.0, 2.0, 3.0, to industry 4.0. Industry 1.0 characterized by the effectiveness and efficiency of human activities supported by the mechanization of production, industry 2.0 characterized by quality standardization and mass production, industry 3.0 characterized by the flexibility of automation and robotbased manufacturing, and mass adjustments. Industry 4.0Employment Jobs and the 2017 Social Outlook Trends predict that total global unemployment in 2018 expected to increase additional earnings by 2.7 million with a total of 204 million people. Likewise, it also predicted that with Indonesia, more and more the same things must be done by western countries. From these data, it is clear that Indonesia's unemployment mostly sourced from secondary schools, both vocational and high school. One reason is the change in the era itself, namely the era of the industrial revolution 4.0, which has changed the way of human activity in scale, complexity, scope, and transformation from previous life experiences. Therefore, students, today must have the ability and skills to predict a rapidly changing future, especially concerning career problems. One way is to optimize the role of Guidance and Counseling in schools.

Guidance and counseling, which is an integral part of education, play an essential role. Through BK, students will give understanding, direction, and prevention of fundamentals. One of them concerns a career problem where currently a career is experiencing degradation. The number of careers that gradually disappear and are no longer needed in human life due to an increasingly evolving era, so students do not experience a career confusion. According to Greenhaus \& Callanan (2006), career vacillation is a condition in which individuals have difficulty making decisions to determine their interests, careers, and jobs. Therefore students need to be equipped early on with knowledge and understanding of careers so that later students are not wrong in choosing direction after graduating from school to become unemployed.

In BK's domain, various services can provide to provide students with an understanding of careers. Such as group counseling, classical guidance, group 
counseling, and individual counseling. Strengthened by the results of research conducted by Priyatno (2016), through BK services in the form of group guidance with discussion techniques, it can improve students' understanding of career exploration.

Career exploration defined as the desire of individuals to explore or search for information on career information sources (Suherman, 2010). Meanwhile, according to Priyatno (2016), career exploration is the ability and all forms of individual activity in finding, obtaining, and managing various kinds of career information. It becomes an alternative career choice to help individuals in choosing and preparing themselves for student careers. From the opinions of some of these experts, the urgency of BK services is apparent in providing understanding and direction to students. Because in the process of career exploration, students are looking for and determine the right career for themselves.

For support services on career exploration, BK media need to improve students' understanding of the services provided. BK media is a tool that can use to channel guidance and counseling messages that can stimulate students' feelings, thoughts, attention, and willingness to direct themselves, understand themselves, make decisions and solve problems they face. Of course, the BK media here adapted to the characteristics of today's student era, where there is the use of digital and technological elements.

\section{METHOD}

The writing method is a literature study (review). Data/information obtained from various literature and compiled based on study results from data/information obtained. The liters used include books, legislation, invitation papers, proceedings, printed and online editions of Imiah journals, research results, and scientific articles sourced from the internet. The types of data obtained are varied, both qualitative and quantitative. The collected data is selected and ordered according to the topic of the study. Then the writing is done based on data that prepared logically and systematically. The data analysis technique is descriptive argumentative. They were writing done by looking at the relevance and synchronization between one data/information one with the data / other information by the topic studied. Next, the conclusion of the paper made. The conclusions obtained referring back to the formulation of the problem, the purpose of writing, and discussion. The conclusions drawn present the subject of the paper and supported with practical advice as to further recommendations.

The presence of industrial revolution 4.0 has influenced human life from various lines of life. One of them is in the realm of education, where education is required to adjust to the development of the times 
and learning styles of students in the 21 st century today. Figure 3. 21 st Century Learning (Trilling and Fadel, 2009) According to Trilling and Fadel (2009), learning in the 21 st century is more oriented towards digital lifestyles, learning research, thinking tools, and the workings of knowledge (see figure 3). Of the four learning styles, the digital lifestyle is the most prominent characteristic, and we can see it in the lives of students today.

\section{DISCUSSION}

The presence of industrial revolution 4.0 has influenced human life from various lines of life. One of them is in the realm of education, where education is required to adjust to the development of the times and learning styles of students in the 21st century today.

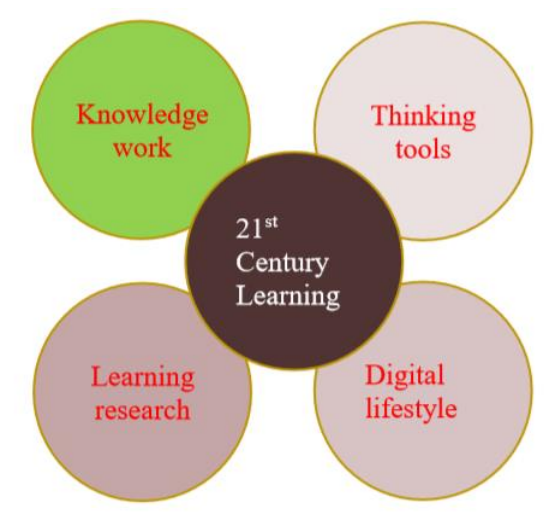

From the learning styles above, educators' role is needed and contributes significantly to success in the achievement of learning today. Educators also required to master a variety of technologies as a medium for learning to be in line with the minds of students today. Without exception, the teacher guidance and counseling in the provision of four services in BK are basic services, individual planning services, responsive services, system support services.

One of the media offered by the author, which can use as a solution to the problems in the background, is the application of DEAR (Digital Exploration Career) on BK services. By using this DEAR, the services provided will be more interactive because it based on hypermedia. The hypermedia component itself makes the files connected by pressing an object/button on one of the screens, which consists of a type of image, sound, video, or multimedia that added with an interactive link. In order to give students the freedom to operate it, hypermedia also refers to computer software that uses the elements of text, graphics, video, and audio that are connected to make it easier for users to switch to information. The flow of preparation of students in facing the industry 4.0 revolution by using this DEAR media in exploring their careers can see in the following picture:

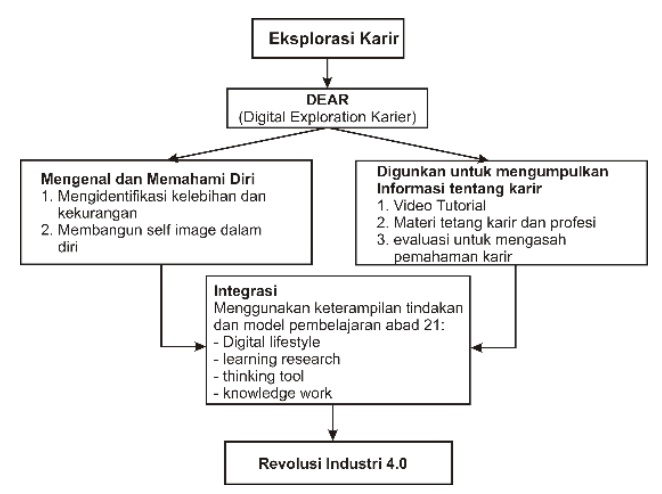
So

me of the advantages, as well as the reasons for the use of DEAR (Digital 
Exploration Career) based on hypermedia as a service medium, are 1) DEAR allows access to a large amount of information non-linearly, meaning that students are free to make choices in getting content. 2) Users, as they wish, can search for information in more depth. 3) Interaction with service material can repeat. 4) DEAR is enjoyable to use. 5) DEAR presents the workings of the human mind. The basic concept, which is the unique feature of DEAR is links and nodes and hypermedia. A link is a link or that makes a connection between nodes and users. At the same time, nodes are parts of the information sources contained in DEAR, covering databases such as sound, video, music, animation, text, graphics, films, pictures, and other data. The presence of DEAR, which is part of hypermedia, presents the same features as described in the hypermedia components. There are an image, sound, video, or multimedia that adds with an interactive link that makes the file connected by pressing an object/button on one of the screens. At the opening, there is an animation in the form of symbols and writing that moves. After that, switch to the login screen, where the user must enter a name to enter the main screen. After inputting the name, the user will take to the main page, which contains menus in the form of material, help, the author, closing, and a few more. On the main page, there is also a window that can be blazed down and up like a smartphone, whose contents are control buttons such as the music volume button, fullscreen and half-screen buttons, and silence buttons for silence. For more details, please see the DEAR main display image below. The first button is the material button. If the user clicks on the button, it will switch to the material page where the material about career exploration and group guidance tutorials about career exploration will present. The second button is the author button. If the user clicks on the button, it will switch to the page where the author's biodata, photo, and social media address will present. The third button is the help button. If the user clicks the button, it will switch to the help page. It will present various instructions and directions regarding the various buttons available in this DEAR media. The fourth button is the settings button. When the user clicks the button, it will switch to the settings page wherein it will present settings features such as screen resolution, back sound in the form of a music list option, and sound volume. The last button is the power button. If the user clicks on the button, then two more buttons will be presented, namely the button to end the DEAR media and the other button to repeat the service by returning to the main page. From the description above, it can conclude that BK media is a means that can support the provision of counseling guidance services primarily in the field of career exploration. The existence of current technology makes it easy for BK teachers to take advantage of broader service media. One of them is the emergence of 
hypermedia, making it easy for students to access the material/content needed because of the incorporation of various media in one interconnected system. The use of hypermedia-based BK media gives BK teachers and students room to interact with each other anywhere and anytime, both when BK service delivery takes place and outside the school in an attractive form.

\section{CONCLUSION}

The presence of DEAR (Digital Exploration Career) as one of the hypermedia-based BK media will provide students with an understanding of career issues to reduce the unemployment rate in Indonesia later. At the same time, prepare candidates for Indonesian superior seeds to master what competencies are needed in the era of the industrial revolution 4.0, so that students will have a competitive spirit to survive and compete globally. In applying the DEAR media itself, demanding not only BK teachers play a role, but students are also required to participate actively. Besides, BK teachers must always update content according to students' needs and existing developments, as well as the need for collaboration with ICT experts when faced with an obstacle. Each use of this media in service delivery also pays attention to students' needs, materials, entertainment as well as evaluations so that the media is effective in service delivery even though sometimes without face to face. So that this media provides a new atmosphere and innovation in the provision of BK services so that they can run dynamically by the times.

\section{REFERENCES}

Hermann, M., Pentek, T., \& Otto, B. 2016. Design Principles for Industrie 4.0 Scenarios. Presented at the 49th Hawaiian International Conference on Systems Science.

Irianto, D. 2017. Industry 4.0; The Challenges of Tomorrow. Disampaikan pada Seminar Nasional Teknik Industri, Batu-Malang.

Mutmainnah, A. N., Yulidah, R., \& Yuniarti, S. 2017. Media Bimbingan Konseling Berbasis Hypermedia. Disampaikan pada Seminar Nasional BK FIP-UPGRIS.

Prasetiawan, H. 2017. Optimalisasi Multimedia dalam Layanan Bimbingan dan Konseling. Prosiding Seminar Bimbingan dan Konseling 1(1): 199-204.

Priyatno, T. 2016. Upaya Meningkatkan Pemahaman Eksplorasi Karir Melalui Layanan Bimbingan Kelompok dengan Teknik Diskusi Kelompok. Psikopedagogia 5(1): 49-56.

Suherman, U. 2010. Konseling Karir Sepanjang Rentang Kehidupan. Sekolah Pasca Sarjana Universitas Pendidikan Indonesia.

Tjandrawina, R.R. 2016. Industri 4.0: Revolusi industri abad ini dan pengaruhnya pada 
bidang kesehatan dan bioteknologi. Jurnal Medicinus 29(1): Edisi April.

Yahya, M. 2018. Era Industri 4.0: Tantangan dan Peluang Perkembangan Pendidikan Kejuruan Indonesia. Disampaikan pada Sidang Terbuka Luar Biasa Senat Universitas Negeri Makassar.

Mosharraf \& Taghiyareh. 2013. Qualitative development of eLearning Environments Through a Learning Relationship Management Methodology. Knowledge Management \& e-Learning: An International Journal (KM\&EL), 5(1)

Microsoft. (2002). Encarta Encyclopedia, 2002. C 1993-2001 Microsoft Corporation [CD-ROOM]. Tersedia: [Oktober 2003].

Lee, J., Lapira, E., Bagheri, B., Kao, H. (2013). Recent Advances and Trends in Predictive Manufacturing Systems in Big Data Environment. Manuf. Lett. 1 (1), 3841.

Kohler, D, \& Weisz, J.D. (2016). Industry 4.0: the challenges of the transforming manufacturing. Germany: BPIFrance.

Baur, C. \& Wee, D. (2015). Manufacturing's Next Act? McKinsey \& Company.

Munir. 2013. Multimedia: Konsep \& Aplikasi dalam Pendidikan. Cetakan Ke-2. Bandung: Alfabeta.

Prasetiawan, Hardi. 2017. Optimalisasi Multimedia dalam Layanan Bimbingan dan Konseling. Prosiding Seminar Bimbingan dan Konseling, 1 (1): 199-204.
Gerjets, P \& Kirschner, P. 2009. Learning from Multimedia and Hypermedia. Knowledge Media Research Center, University of Tubingen, $T^{\prime}$ ". ubingen, Germany. DOI: 10.1007/978-1-4020-9827-7 15

Kaharu, S N. 2015. Pengaruh Hypermedia Terhadap Peningkatan Kemampuan Berfikir Kreatif Mahasiswa dalam Pembelajaran Rangkaian Listrik Arus Searah. Jurnal Elektronik Sistim Informasi Dan Komputer (Jesik), 1 (1)

Winarno et al. 2009. Teknik Evaluasi Multimedia Pembelajaran: Panduan Lengkap untuk Para Pendidik dan Praktisi Pendidikan. Yogyakarta: Genius Prima Media.

Anitah, Sri. 2009. Media Pembelajaran. Surakarta: Yuma Pustaka.

Ansori, M. Iksan. 2012. Efektivitas Pembelajaran yang Menggunakan Hypermedia dan Power Point terhadap Prestasi Belajar Mata Pelajaran Pendidikan Agama Islam Ditinjau dari Kemampuan Visuospasial di SMA Negeri Se-Kabupaten Nganjuk Tahun Ajaran 2012/2013. Tesis. Surakarta: Program Pasca Sarjana Universitas Sebelas Maret.

Montu, Erlin, Sunarno, Widha, \& Suparmi. 2012. Pembelajaran Fisika dengan Inkuiri Terbilang Menggunakan Hypermedia dan Media Riil Ditinjau Gaya Belajara dan Kemampuan Awal. Jurnal Inkuiri, 1 (1), hlm. 10-16 
Suherman, Uman. (2010). Konseling Karir Sepanjang Rentang Kehidupan. Sekolah Pasca Sarjana Universitas Pendidikan Indonesia.

Gladding, Samuel T. (2012). Konseling Profesi yang Menyeluruh. Jakarta: Indeks

Rizki Wanda F \& Wiryo Nuryono. (2014). Survei Tentang Persepsi dan Kesiapan Konselor terhadap Bimbingan dan Konseling Berdasarkan Kurikulum 2013 di SMA Surabaya Selatan. Jurnal. Bimbingan dan Konseling Universitas Negeri Surabaya Trilling, B \& Fadel, C. (2009). 21st-century skills: learning for life in our times. US: Jossey-Bass A Wiley Imprint.

Nursalim, M. 2010. Media Bimbingan dan Konseling. Surabaya: Unesa University Press. 